\title{
Management and labour in an integrated crop-livestock-forestry system in Roraima, Brazilian Amazonia
}

\author{
Amaury Burlamaqui Bendahan ${ }^{1, *}$, René Poccard-Chapuis ${ }^{2,3}$, Roberto Dantas de Medeiros ${ }^{1}$, \\ Newton de Lucena Costa ${ }^{1}$ and Jean-François Tourrand ${ }^{3,4}$ \\ ${ }^{1}$ Embrapa Roraima, Rod. Br 174, km 8, Distrito Industrial, CEP: 69.301-970, Boa Vista, Roraima, Brazil \\ 2 CIRAD, UMR Selmet, Belém PA, Brazil \\ ${ }^{3}$ Univ Montpellier, Montpellier, France \\ ${ }^{4}$ CIRAD, UPR GREEN, 34398 Montpellier, France
}

\begin{abstract}
Livestock production systems in the Amazon have caused substantial environmental damage. With the pressure to improve and increase production on limited lands, and the new ways of evaluating systems, farmers are looking for alternatives to livestock production. The scientific community began to promote incorporating trees as a component of livestock systems, as an alternative to livestock specialization. However, these systems were not adopted as expected. One of the hypotheses is that this alternative requires a complicated management. In this context, the objective of this study was to describe the implications for the management of cattle farms and the work necessary to include an integrated croplivestock-forestry system (CLFIS) in cattle farms in Roraima State. To address this objective, we used secondary government data, interviews, and farm monitoring. The results showed that, regardless of the scale of production, more components in the CLFIS result in more activity differentiation, more diversification of knowledge and work, and a more complicated management. In conclusion, the adoption of a CLFIS to replace the exclusive production of livestock results in losing the flexibility and characteristics of livestock production in Amazonia. The increase in the average age and the low level of schooling of farmers and rural workers are factors that make it difficult for them to internalize, understand and adopt CLFIS. Labour and management are complicating factors contributing to the low level of CLFIS adoption by Roraima State farmers.
\end{abstract}

Keywords: labour / skill training / farm management / agrosilvopastoral systems / agroforestry

Résumé - Gestion et travail dans les systèmes intégrés culture-élevage-forêt dans l'État du Roraima, Amazonie brésilienne. En Amazonie, les systèmes d'élevage ont causé de nombreux dommages environnementaux. Mis sous pression par des réglementations strictes, par de nouvelles méthodes d'évaluation et par la nécessité de produire plus sur des surfaces désormais restreintes, les producteurs cherchent des alternatives. La communauté scientifique a commencé à promouvoir des systèmes agricoles intégrant une composante arborée comme alternative aux monocultures et à la spécialisation en élevage. Cependant, ces systèmes n'ont pas atteint les niveaux d'adoption espérés. Une des hypothèses est la gestion très compliquée qu'ils demandent. Dans ce contexte, l'objectif de cette étude est de décrire les implications en termes de gestion du travail liées à ces systèmes dans les fermes bovines de l'État de Roraima, au nord de l'Amazonie brésilienne. Pour atteindre cet objectif, nous avons utilisé des données secondaires publiques, des entretiens et des suivis d'exploitations. Les résultats montrent que, indépendamment de l'échelle de production, la multiplicité des composantes des systèmes agriculture-élevage-forêt (CLFIS) se traduit par des activités plus différenciées, par davantage de diversification des connaissances et du travail, et par une gestion plus compliquée. En conclusion, l'adoption des CLFIS pour remplacer l'activité d'élevage spécialisée entraîne une perte de flexibilité, caractéristique importante de l'élevage en Amazonie. L'augmentation de l'âge moyen et le faible niveau d'éducation des agriculteurs et des travailleurs ruraux

*Corresponding author: amaury. bendahan@embrapa.br 
sont des facteurs limitant la compréhension et l'adoption des CLFIS. Le travail et la gestion plus complexes contribuent au faible taux d'adoption des CLFIS par les agriculteurs de l'État du Roraima.

Mots clés : travail / développement des compétences / gestion de l'exploitation agricole / système agrosylvopastoral / agroforesterie

\section{Introduction}

The expansion of cattle ranching in the Amazon was based on technical and economic issues because of the dynamics of employment and organization of the territory (Tourrand et al., 2006). In addition to government incentives, ranching proved to be an excellent alternative to other means of land use, especially because of a combination of factors and characteristics such as favourable weather conditions, ease of structuring the production chain, liquidity, storage of animals in their own pasture, alternatives to savings for producers, and ease of management (Veiga et al., 2004). On the other hand, the actual livestock production systems cause substantial environmental damage and generally result in long-term sustainability problems (Dias-Filho, 2011). In Roraima State, the same dynamic has been observed (Arco-Verde, 2008).

With pressure to increase and improve production and new ways of assessing the systems (social, technical, economic, environmental and landscape), farmers are seeking other alternatives. Research and development institutions have been called upon to address these issues. When the scientific community began to promote agricultural systems that incorporated trees as an alternative to monocultures and livestock specialization, it was understood that meeting the new challenges of environmentally friendly production would bring major economic and social gains (Veiga and Tourrand, 2004). These systems, generating ecosystem benefits and services, meet the challenges posed to farmers and the scientific community seeking production alternatives to traditional extensive livestock farming.

However, these multi-component and multi-product systems were not adopted as expected. Although research on their adoption is scarce, several authors note barriers to adopting these practices. Among these, less flexibility to modify the arrangements of the tree component is cited due to the need for greater skills and dedication by those involved. Such barriers suggest the need for improved management and more skilled labour (Mercer, 2004; Veiga and Tourrand, 2004; Brienza Júnior et al., 2009). In 2008, Embrapa (Brazilian Agricultural Research Corporation) created a national research programme in which the Roraima Unit participated to study the introduction of a production system called crop-livestockforestry integration systems (CLFIS). These systems integrate annual crops, livestock and trees in the same space, in combination, succession or rotation.

Additionally, Brazilian producers often pay more attention to technical details than to management, and there is resistance to changing their mode of action, even in the face of constant change (Rezende and Zylbersztajn, 1999; Queiroz et al., 2008).

It has been observed that the majority of Brazilian producers have little knowledge on management practices; and the production and transfer of technologies adapted to different contexts are inefficient, and their methods inadequate (Batalha et al., 2005; Nagaoka et al., 2011).

In this context, this study aimed to describe the implications for labour and farm management based on the inclusion of CLFIS in cattle farms.

\section{Methods}

To address our objective, we focused on describing the rural characteristics of Roraima State, the profile of farms, the farming practices, the practices of the farms that adopted the CLFIS, and the quantification of their work and needs. Therefore, we determined the farm management for the CLFIS and operational management of the production system in Roraima.

To describe the rural characteristics of Roraima, we identified the origins of those in charge of managing the farms, and we analysed where they live, the indicators of the quality of their primary and secondary education, their incomes and the size of their herds and farms. To do this, we analysed secondary data from the Brazilian Institute of Geography and Statistics (IBGE), the National Institute of Colonization and Agrarian Reform (INCRA), the National Institute of Education (INEP) and the Agricultural Defence Agency of Roraima (ADERR). To understand the dispersion of ranching and grasslands throughout the State, we analysed the data of the project "TerraClass" of INPE and Embrapa and the census database from IBGE.

To analyse the profile of ranches and farms of Roraima State, we used the results of interviews that were conducted in July and August 2013. Key actors in the chain of livestock production were also interviewed using semi-structured interviews. This methodology was employed with key actors because it has been applied in previous research projects and because of the limitations of traditional forms of interviews with closed questionnaires (Chambers, 1994; Wood, 2015). The number of interviews has not previously been quantified, since it is based on the principle of redundancy; in other words, further interviews were not conducted when the last one produced nothing new. The identification of key actors to interview was based on knowledge accumulated by the authors over the years, recommendations made by interviewees during the research, and the emergence of new questions during the interviews that required research for specific information and therefore specific informants. The key actors interviewed were one farmer from a cooperative, two farmers, three producers who practised crop-livestock and one CLFIS, two representatives from small-scale diversified production units, two representatives of the Federal and State governments related to agriculture, two technicians, one credit representative, and two merchants (Tab. 1).

In conducting the interviews, a standard was not followed; it was always sought to adapt the interviews to the 
interviewees' characteristics and the nature of the information they provided. With this perspective, a questionnaire was not used. The interview guidance was to start the conversation with an initial open question that was related to the factors being assessed and to use the knowledge gained from that question to guide the rest of the interview. Triangulation was used to verify the generated information. A scenario technique was used during the conversation, where the respondent was put in unusual situations to check the consistency of answers from the different respondents. The repetition among the responses of each key player allowed progress in building an understanding of the factors related to management of farms. The search for new informants continued until no more new knowledge was gained from the interviews and the triangulation process generated no more uncertainties. From the point of determining there were no more relative redundancies, it was considered that enough information was already held to understand the system. Certainly, another informant would have brought more information, but it would not have been of high importance or of a nature to change the overall vision for what was being sought to understand. After each interview, reports were produced to secure the information.

The initial question of the interview was: How do you develop the work (activities) on your farm? Farmers were required to present their farm. The focus was the management, the contribution of livestock to the farm and the family's income, their relationship with other actors, the involvement of the family, the technologies and forms of planning and controls, and the infrastructures found on the farms.

To describe the activities and farming practices, we used the same methodology with the keys actors and the interviews previously described. However, the focus of these interviews was to distinguish between the various activities and practices on a farm and determine who assumes these functions, at different scales of production. Before ending the interview, farmers were asked to build a practices calendar. We used two metal plates, $0.5 \times 1 \mathrm{~m}$ in size, with decennial divisions, and magnets with pictures of activities and practices with periods identified as very dry, dry, slightly damp, wet and very wet.
Then, the magnets relevant to their activities and practices were placed in the period of the year when they were performed.

To determine the practices incorporated into the farms that adopted CLFIS, we conducted interviews with nine technicians, one forester, one CLFIS producer, two farmers, four grain farmers and two representatives of small-scale diversified production. Initially, the interviewees were asked to validate the list of practices in their respective area and other practices. Then, the interviewees were asked to grade activities, from 1 to 5 , in which 1 indicated easy activities to perform and 5 indicated the most difficult ones. Finally, they were asked to indicate their needs and the time required to meet them. To complete the interviews, we utilized the same method of building a calendar, but this time, the data was generated from six technicians and five farmers of grain and trees.

Finally, we conducted a workshop with five technicians and one producer, who participated in implementing and conducting experiments in experimental stations and farms, and members of the CLFIS project at Embrapa. The focus was on building a calendar of practices and discussing the challenges to increasing the CLFIS on cattle farms.

In total, 22 interviews were conducted, and the questionnaires were subdivided into four themes and answered at the same time, according to the relevance and knowledge of the key actors. For the description of the rural characteristics of Roraima and the description of the activities and practices used by the farmers, 16 interviews were conducted with the same key actors. To construct the calendar on the practices used by the farmers and determine the incorporated agronomic practices, seven agricultural technicians, four grain producers and a producer of forest species with great interest and technical training on the specifics of the theme, were interviewed in addition to the key actors (Tab. 1).

To determine the increment of work (man day ${ }^{-1}$ year $^{-1}$ ) needed on a farm that includes the CLFIS, we monitored private farms during all the three years of the experiment, through weekly visits during the cropping season and monthly

Table 1. Quantitative analysis of the responses of the key actors to the addressed questions.

Tableau 1. Analyse quantitative des réponses des acteurs-clés selon les questions posées.

\begin{tabular}{|c|c|c|c|c|}
\hline Key actors & $\begin{array}{l}\text { Description of rural } \\
\text { characteristics } \\
\text { of Roraima }\end{array}$ & $\begin{array}{l}\text { Description of } \\
\text { activities and } \\
\text { farming practices }\end{array}$ & $\begin{array}{l}\text { Calendar } \\
\text { construction } \\
\text { of the practices } \\
\text { used by farmers }\end{array}$ & $\begin{array}{l}\text { Determination of } \\
\text { the agricultural } \\
\text { practices incorporated } \\
\text { and adopted by farmers }\end{array}$ \\
\hline
\end{tabular}

Farmer cooperative

Farmers

Producers who practise crop-livestock

Producers who practise CLFIS

Small-scale diversified production

Representatives of the Federal and State governments

Technicians

Credit representative

Merchants

Forester

Grain farmers

Total

1
2
3
1
2
2
2
1
2

2

3

1

2

2

2

1

2

16

16
2

3

1

2

9

1
4

22
2

1

2

9

1

4

22 
visits in the off seasons. The items monitored were time spent on manual activities and activities with tractors, time spent on management of dairy cattle, non-ordinary events that influenced management of the systems, and for which components (tree, grain and animal) infrastructure was used.

For the management factor, we sought to identify farmers' knowledge of farm management and production systems. Then, we focused on determining which types of controls were used, formal and/or informal in the economic, financial, production and commercial aspects of their operations.

To analyse the need for training workers on farm management for a CLFIS and operational management of the production system for the farms of Roraima State, we carried out joint analyses on the results of the interviews, the workshop and the monitoring, previously described.

\section{Results}

\subsection{Rural characteristics of Roraima State}

Ranching is dispersed throughout all municipalities in Roraima State. Ranching is practised on native grasslands, in a region of savannas that covered 404,385 ha in 2006 (IBGE, 2006), and on cultivated pastures in forests, which consisted of 353,624 ha in 2012 (INPE and Embrapa, 2014). The first estimates of ADERR in 2016 consisted of a herd of 850,000 heads spread over 6896 farms.

As for the origin of those in charge of managing the farms with livestock activity, approximately $52 \%$ come from the northeaster region of Brazil, where the Maranhão State stands out with $36 \%$ of all farm managers, and another $17 \%$ were born in other States in the northeaster region (IBGE, 2006). Roraima accounts for $24 \%$ of the managers, and other States in the northern region account for $11 \%$. The regions of the midwest, southeast and south each contribute to $4 \%$ of the total of all managers (Fig. 1a). Approximately $88 \%$ of these managers live on the farm itself, $5 \%$ in rural areas, $5 \%$ in an urban area and $2 \%$ in other municipalities (Fig. 1b) (IBGE, 2006).

On one hand, the indicators of the quality of primary and secondary education show that education in rural areas is deficient (INEP, 2014); on the other hand, it appears there has been an increase in the number of places that offer higher education and vocational courses in recent years.
Rural income is low in Roraima State, and many producers residing there are below the poverty line (INCRA, 2016).

\subsection{Profile of ranches and farms of Roraima State}

Ranchers do not easily incorporate new technologies, and many have low levels of schooling or are illiterate. They are well connected. The network of relationships is useful to them for marketing, procurement of supplies, aiding in sporadic services, animal health services and the incorporation of technologies into the system. A significant number of farmers, especially on small farms, are getting older, and their sons are migrating to the city.

Farmers are "diverse". Few farmers have livestock as their only source of income, even though, for some livestock is the most important activity. When other rural or urban activities thrive, profits are invested in livestock; otherwise, this is the first source of funds the farmer uses, even if it hinders production. Farmers seem to need other activities either rural or urban, mainly due to the need of the owners and their families for a continuous cash flow for daily expenses.

Farm management is intuitive, and farmers lack the ability to prioritize activities. To these farmers, livestock production appears to be an activity "autonomous", not needing to be accompanied daily. There is virtually no formal education in management. Strategic analysis, planning and management are uncommon. Economic, financial and zootechnical controls are rare, thus farmers cannot use information sources for decision making.

\subsection{Activities and farming practices}

Livestock systems, including the extensive one, have significant quantities of functions, practices and activities. On farms with large herds that are more structured and as a rule, the division of work is carried out at management levels of officers, cowboys and their assistants. Still, someone may be hired for a specific service, such as maintenance of infrastructure and invasive plants. On farms with a low production scale, family members or employees take on the farm functions. For example, the owner operates as a manager or as an officer who works with the cowboys. On smaller scale

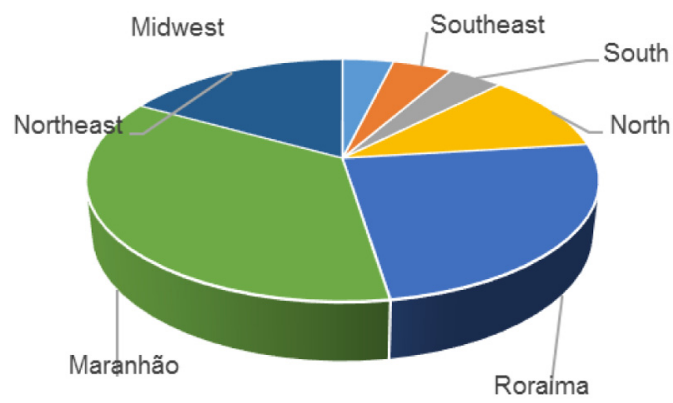

a

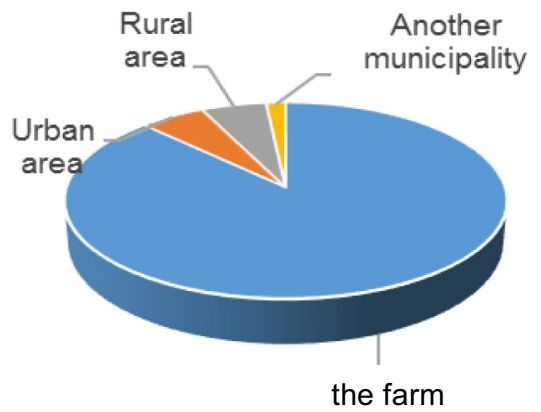

b

Fig. 1. Origin (a) and place of residence (b) of the person responsible for the management of farms in the Roraima State (IBGE, 2006).

Fig. 1. Origine (a) et lieu de résidence (b) de la personne responsable de la gestion de l'exploitation dans l'État du Roraima (IBGE, 2006). 
farms, especially where no one is hired to work, these functions are all performed by one or two persons. This fact means that some practices and activities are not carried out. This can also occur on farms where work is hired. Moreover, there is the perception that, in general, farming practices are considered easy to perform, and there is a degree of flexibility as to when they are performed.

\subsection{Practices incorporated by cattle farms adopting CLFIS}

To better understand the results of this study, the practices that should be incorporated with the adoption of CLFIS systems in livestock farms are divided into 4 groups (Tab. 2).

The interviewers considered that the practices that require knowledge on machine operation and simpler equipment control belong to Group 1. These practices are of intermediate difficulty, and the skills can be acquired through training and practice over one year. In another aspect, the practice of grain harvest, also said to be of intermediate difficulty, requires greater attention because it involves a more refined level of regulation and equipment operation and more experience to decide on the best time to harvest to reduce waste.

Practices belonging to Group 2 (apart from soybean and cowpea inoculations, which were considered of low difficulty, and the skill can be acquired in the first year) were labelled as high difficulty; they involved learning information and required years of practice. However, it is a difficult area, because new things always occur, both in relation to pests that arise as well as new control methods. The analyses of the interviews show that some factors were predominant, so that this level of difficulty was considered one of the most important to the agronomic success of crops:

- the producer does not have the right product at the right time due to lack of inventory planning or lack of availability in the local market;

- similarly, lacking the appropriate equipment could be due to either its out of use or unavailable in sufficient quantities, in order to carry out an activity at the right time;

- lack of sufficient and/or trained personnel;

- finally, some farmers do not have the technical expertise to identify the ideal time to carry out the practice, mainly pest control.

Grain planting differs from Group 2, as it requires more attention than years of experience. In this practice, many variables interrelate to achieve the desired distribution and the quality of seeds. The tillage system, which involves herbicide use in desiccation and making straw, means this system requires not only more training but also more years of experience.

The activities of acquisition of supplies and commercialization of production (Group 3) were considered by all respondents as being highly difficult, and grasping the necessary skills was difficult. For input acquisition, all respondents established noted that the need for more time to obtain experience and activities with a higher degree of difficulty was crucial. There was a lack of formal knowledge on negotiation techniques or a perception of the lack of marketing channels and lack of the free flow of information on prices, demand and product supply. Finally, it was observed that more time for planning is necessary, despite it was not formalised and there is little flexibility in the implementation period.

Group 4 included forestry practices, preparation of seedlings and pits, acclimatization and planting of seedlings which are performed in the first year but cannot be neglected. Regardless of farm size, monitoring by experienced people must be provided. Maintenance practices such as weeding, mowing and pruning were not considered difficult to grasp in terms of the necessary skills. Both chainsaw use and measurement of height and circumference at chest height were considered of medium difficulty. Respondents believe that competence in the use of chainsaws can be gained in the first year. Evaluation measurements such as pruning were suggested as a more detailed practice but with a relative ease of implementation. As for livestock practices, there is a certain flexibility with the time of the operations, during the year.

\subsection{Quantitative labour}

The additional labour ( $m a n$ day $^{-1}$ year $^{-1}$ ) needed, due to the inclusion of CLFIS in subsistence dairy farms in the forested region with 10 ha and a herd of 5 cows, was $80 \%$ higher than the $91-$ man day $^{-1}$ year $^{-1}$ calculated for this type of farm without CLFIS. For fattening beef cattle farms, in forested regions with 200 ha area of pastures and 238 heads, it was estimated that 480-man day ${ }^{-1}$ year $^{-1}$ are needed. With CLFIS included, there was an increase of $21 \%$ or 885 -man day $^{-1}$ year $^{-1}$. Finally, the labour increase in farms in Roraima's savanna with 1000 ha of pasture and 200 cows, because of the inclusion of CLFIS, was $30 \%$, or $1152-$ man day $^{-1}$ year $^{-1}$.

Table 2. Groups of annual crops and forestry practices.

Tableau 2. Groupes de pratiques en cultures annuelles et foresterie.

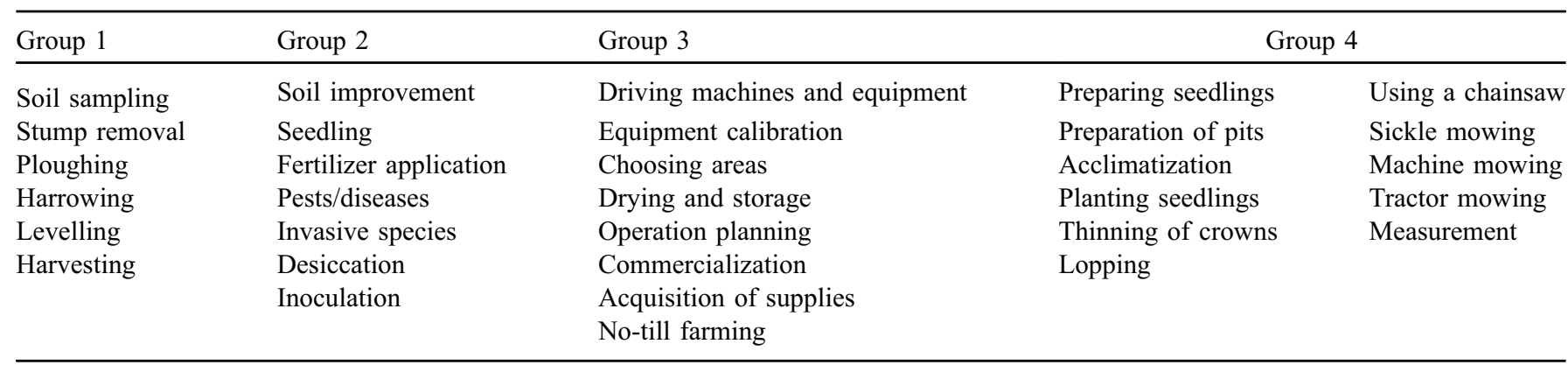




\subsection{Qualitative labour}

The CLFIS requires the inclusion of new practices and more operational work in a farm production system. The new incorporated practices are not restricted to those related to the new components, grain and forestry; they include practices related to livestock and management, which are improved by the implementation of tools adapted to the different contexts. The farms of Roraima State do not possess the skilled technical labour to meet the demands generated by the inclusion of grain and tree components. Therefore, continuous training plans on techniques must be incorporated into the daily management of the farm. In addition to training on the implementation techniques and carrying out a CLFIS, training should also include financial and accounting management, prioritization and focus, marketing and trading, and human resource management and planning for the short, medium and long term.

\subsection{Farm management for CLFIS}

It is understood that the intensification of farm management due to CLFIS requires adjustments that go beyond the inclusion of the new components to the farm production system, given that the entire operation of the farm is changed. The increase in components, activities and practices complicate the management of the farm. Other contributing factors are new legislation, increased funding, new markets and different logistical elements for new supplies and products. These multi-component and multi-product systems are more complex than livestock farming, so understanding or improving the producer's systemic vision, in which the results come not only from the sum of their harvests but also from interactions between components that arise from relationships, namely, cause and effect, temporal, nonlinear, retroactions, feedback or even indirect interactions, produce other less visible results that contribute to future earnings and the sustainability of the entire production system and thus their business.

\subsection{Operational management of the production system}

The intensification of farm management by CLFIS, especially agro-forestry-pastoral farms, based on the increased use of supplies and technology different from the normal livestock systems, demands a change in the daily running of farms. The number of practices, activities and technologies that are incorporated requires new knowledge and constant updating and management control.

In complex management, when the results that emerge from interactions between components (complexity) are not taken into account, management tools such as the creation of an annual calendar, that both serves planning and monitoring practices and activities, and contains information on agricultural practices and management activities, marketing and supplies acquisition, can be used to overcome this complexity in the context of State livestock farms.The management of complexity, understood as the income, not only is the endproduct of the components but also originates from the interaction between all components of the CLFIS.

\section{Conclusion}

The increase in the average age and the low level of schooling of farmers and rural workers are factors that make it difficult to internalize, understand and adopt CLFIS. The types of ranches and farms in Roraima State are barriers to largescale expansion of CLFIS in the State. The adoption of CLFIS as a replacement for exclusive livestock activity results in the loss of temporal flexibility in terms of practices implementation. Labour and management are complicating factors contributing to the low level of CLFIS adoption by Roraima State farmers. The key factors relevant to making management work are improving the distribution and coordination of tasks and the constant training of those involved. Management types most commonly used by farmers on the Roraima State, especially the systems based on slash and burn, cannot be used in the CLFIS, which means that training plans will need to be combined.

\section{References}

Arco-Verde MF. 2008. Sustentabilidade biofísica e socioeconômica de sistemas agroflorestais na Amazônia brasileira. Tese Doutorado, Universidade Federal do Paraná. (Brazil.

Batalha M, Bunain A, Souza Filho HM. 2005. Tecnologias de Gestão e Agricultura Familiar. In: Souza Filho HM, ed. Gestão Integrada da Agricultura Familiar. São Carlos (Brasil): EDUFSCAR, pp. 43-66.

Brienza Júnior S, Maneschy RQ, Mourão Júnior M, Filho JG, Gonçalves D, Gama M. 2009. Sistemas agroflorestais na Amazônia brasileira: análise de 25 anos de pesquisas. Pesquisa Florestal Brasileira 60: 67-76. DOI: 10.4336/2009.pfb.60.67.

Chambers R. 1994. The origins and practice of participatory rural appraisal. World Development 22(7): 953-969.

Dias-Filho MB. 2011. Os desafios da produção animal em pastagens na fronteira agrícola brasileira. Revista Brasileira Zootecnia 40: 243-252.

IBGE (Instituto Brasileiro de Geografia e Estatística). [2016/03/01]. Censo Agropecuario 2006. http://www.ibge.gov.br/home/estatis tica/economia/ppm/2013/default xls grandes regioes.shtm.

INCRA (Instituto Nacional de Colonização e Reforma Agrária). [2016/03/18]. Painel dos Assentamentos. http://painel.incra.gov.br/ sistemas/index.php.

INEP. [2016/03/20]. (Instituto Nacional Estudos e Pesquisa e Educação). Censo Escolar 2014. http://portal.inep.gov.br/basicacenso.

INPE and Embrapa. [2016/03/07]. TerraClass Sumário Executivo: Levantamento de informações de uso e cobertura da terra na Amazônia. www.inpw.br/cra/projetos_pesquisas/sumario terra classe 2010.pdf.

Mercer DE. 2004. Adoption of agroforestry innovations in the tropics: a review. Agroforestry Systems 61: 311-328.

Nagaoka MP, Ensslin L, Ensslin SR, Nagaoka AK. 2011. Gestão de propriedades rurais: processo estruturado de revisão de literatura e análise sistêmica. Revista Brasileira Agrociências 17: 410-419.

Queiroz TR, Lourenzani WL, de Souza Filho HM. 2008. Scorecard sistêmico: modelo de gestão para empreendimentos rurais familiares. Organizações Rurais Agroindustriais \& Agroindustriais 10(1): 123-136.

Rezende CL, Zylbersztajn D. 1999. Uma análise da complexidade do gerenciamento rural. In: IV Seminários em Administração da FEAUSP. São Paulo: FEA, pp. 1-15. 
Tourrand JF, Veiga JB, Burlamaqui AB, Poccard R, Piketty MG. 2006. L'Amazonie pâturée. In: XIII Rencontres autour des recherches sur les ruminants. Paris (France) : l'Institut de l'Élevage, pp. 345-348.

Veiga JB, Tourrand JF. 2004. Potencial e adoção de sistemas silvipastoris na Amazônia Oriental. In: Sistemas agroflorestais, tendência da agricultura ecológica nos trópicos: sustento da vida e sustento de vida. Campos dos Goytacazes: SBSA/CEPLAC, pp. 107-124.
Veiga JB, Tourrand JF, Piketty MG, Poccard-Chapuis R, Alves AM, Cordeiro MT. 2004. Expansão e trajetórias da pecuária na Amazônia: Pará, Brasil. Brasília (Brasil): Editora UNB, 162 p.

Wood CH. 2015. Introdução metodológica ao estudo da pecuária, do uso da terra e do desmatamento no Brasil, no Peru e no Equador. In: Pecuária, Uso da Terra e Desmatamento na Amazônia. Brasília: $\mathrm{UNB}, 284 \mathrm{p}$.

Cite this article as: Bendahan AB, Poccard-Chapuis R, de Medeiros RD, de Lucena Costa N, Tourrand J-F. 2018. Management and labour in an integrated crop-livestock-forestry system in Roraima, Brazilian Amazonia. Cah. Agric. 27: 25005. 